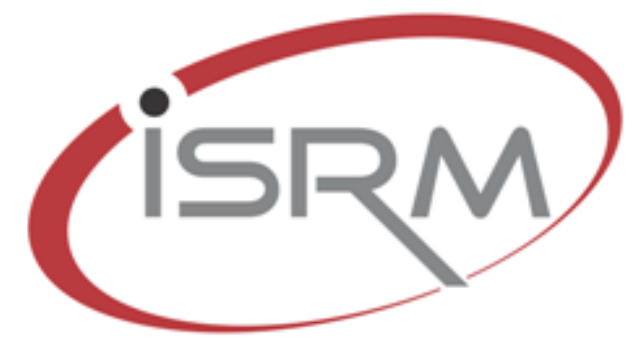

Instituł für Service und Relationship Management
Universität Leipzig

Wirtschaftswissenschaftliche Fakultät

Institut für Service und Relationship

Management

Lehrstuhl für BWL, insbs. Marketing

Referenz Verlagsversion/Published in

final edited form as:

J Bus Mark Manag, 2010 December; Vol.

4, No. 4, pp. 217-230

DOI: 10.1007/s12087-010-0045-1

\title{
Signs AND PRACTICES: COORDINATING SERVICE AND RELATIONSHIPS
}

\author{
Helge Löbler \\ Leipzig University
}

\begin{abstract}
The world is full of signs (symbols, signifiers). They guide us in supermarkets, on highways and in airports. They even guide us to the right bathroom. Signs have a huge impact if they are used as logos or in advertisements. Signs also help us when we read manuals or when we use a remote control. Signs are used everywhere. Signs render service as they are "applications of skills and knowledge for the benefit of another party" (Vargo and Lusch 2004, 2008). Like all offerings signs only render service if they are used in some way. This article will argue that the usage of signs depends on the practices they are embedded in. It is argued that signs do not gain their full meaning and do not serve or create any value unless they are embedded in practices. Since signs are explicit and practices mainly implicit they are both necessary to serve and more importantly to (co-)create value. Signs and practices are two sides of the same coin so both they (and their interrelation) have to be understood in order to offer a better service.
\end{abstract}

\section{Keywords}

signs, practices, service, relationship, coordination 


\section{Introduction}

Signs guide us when we are shopping in supermarkets or driving on highways. They give us orientation to find what we are looking for, whether we are looking for a particular product or want to find a certain exit on the highway or even the right bathroom. Hence signs render service in helping to find what we are looking for. In addition, in many service situations customers are not interacting directly face-to-face with people but with technical devices/technologies. This is true for commonly used teller machines, for online-banking, interactive voice responses, interactive kiosks, and artificial virtual agents such as IKEA's Anna, etc. Not to forget manuals, which we read over and over, trying to understand them. When one does not directly interact with other people face-to-face the "interaction" is very often reduced to reading and writing, i.e. to signs and their "understanding". The signs and the electronic devices are service according to Vargo and Lusch $(2004,2008)$ in so far as they are applied skills and knowledge for the benefit of another party. Since the (inter-)actions in these kinds of situation are mainly performed by signs (including signs used by electronic devices) the customer cannot get into direct face-to-face contact, hence cannot check with someone else directly if there is any kind of problem. In these kinds of situation it is very important that the signs to be read are intelligible; that they can easily be understood. Otherwise the interaction may fail and the customer (as well as the service provider) will be unsatisfied.

Research has shown that abstract instructions are less clear compared to examples because examples are directly linked to practices, whereas abstract instructions are not. The postmodern perspective - especially the poststructuralist perspective - supports this result in arguing that signs and/or signifiers are not connected to any signified. Baudrillard (1975, p. 128) and Derrida $(1976,1977,1978)$ totally disconnected the sign as a signifier from the signified: "The sign no longer designates anything at all. It approaches its true structural limit which is to refer back only to other signs". From this perspective Cherrier and Murray (2004, p. 513) conclude "In the post-modern era, there is no longer an attempt to refer back to nature or ground the representamen." This perspective is used by Venkatesh et al. (2006, p. 251) in their emphasis on "[...] (re)considering the starting point of our disciplinary analysis to be the market [...] as opposed to marketing [...]," where they considered the "[...] market as a sign system [...]" (2006, p. 258). But if markets and signifiers in general are "only" plain sign systems how (if at all) are these sign systems linked to activities or (inter-)actions (doings)? How are they understood to be transformed into (inter-)action?

To answer this question Practice Theory will be used as it serves as a "[...] nexus of doings and sayings" (Schatzki 1996, p. 89). Since practices are mostly implicit or tacit (Reckwitz 2002) whereas signs are by definition explicit, I will distinguish two domains or arrays: an explicit domain with mostly signs and signifiers and an implicit domain with mostly practices. Here I follow Friedland and Alfort (1991) in New Institutionalism as well as Matten and Moon (2008) in Corporate Social Responsibility.

I will suggest that signs/signifiers explicitly configurate and coordinate different realms of (inter-)activities (relationships and service) whereas practices implicitly configurate and coordinate different realms of (inter-)activities. In doing so practices serve as an important element of assigning meaning to signs and signifiers. The intelligibility of signs and signifiers, I will argue, is mainly assured through their connection to practices. This argument goes back to Wittgenstein "The meaning of a word is its use in the language" $(2008, \S 43)$ and its use in the language is a practice. The important relationship between the intelligibility of signs and action/doings/practices has been further developed in the field of Social Construction (Gergen, 1991, 1994, 1999), of Neuroscience (D'Ausilio et al. 2009; Boulenger et al. 2008; De Jaegher and Di Paolo 2007), of Philosophical Linguistics (Lakoff and Johnson 1999) and of computer science (Knott 2010). These developments will be used here as a basis for my main proposition 
that signs as service gain their intelligibility and value as a service by being embedded in practices. The two levels of configuration or coordination (signs and practices) and their connectedness will serve as a frame for analyzing very different kinds of service, their success and the relationships which are activated by these services. Thus this perspective supports the A2A (actor to actor) approach recently introduced by Vargo and Lusch (2010).

The article is organized in five sections. The second section will be used to look at an important condition under which signs/signifiers are seen as service. This condition is also required to (co-)create value. The third section will then firstly introduce the deconstructivist perspective of post-structuralism - that signs/signifiers refer only to signs/signifiers but nothing else - and secondly identify three realms of sign coordination. In the fourth section we briefly discuss the theory of practices as a nexus of "doing and saying" with its implicit character and then connect it to the realms of sign coordination. The final section discusses the danger of the disembedding of service if signs are not intelligible as service on the basis of practices.

\section{When Signs are Service}

According to UNESCO (1968, p. 8) illiteracy is "a major obstacle to the effective enjoyment of human rights". Hence literacy is a required condition. Since people in the "civilized" world mostly do not suffer from illiteracy they often take literacy for granted, as reading is a day-today practice. Without literacy the day-to-day coordination of people in the modern world would be virtually impossible. E-mails, the internet and newspapers, to name only some of the media in the civilized world, would not be usable. The modern world is full of signs/signifiers and words. And the majority of signs can be read by the majority of people in the western world. All the signs/signifier and words render service and create value if they are read and understood. But being able to read does not necessarily mean being able to understand. This is clear if we remember all the manuals we have tried to understand, reading them over and over again, or thinks of getting a ticket from a ticket machine in a foreign country, even when there is an English description. When trying to operate new electronic devices people often use only 20 $30 \%$ of the features these devices offer because they do not understand how to use the others. All these texts and devices only render service if people understand how they can be used. It does not matter if users understand items in the same way as was intended by the creator or producer; the important thing is that the user finds at least one means of valuable usage which may or may not be different to the "intended use". Their way of using an item is at the same time at least one way of understanding the item. I am not saying that understanding is the same as using. We may understand how to fly an aircraft but at the same time we are not necessarily able to fly it. And, if so, we cannot use it and cannot (co-)create value. If we then find a pilot who is able to fly the aircraft we can use it (sitting in the cabin enjoying the flight) while the pilot does all the work. The important point here is that both flying the aircraft and enjoying the flight are practices, and by executing (practicing) the practices we (co-)create value-just knowing how to fly or just knowing how to enjoy a flight does not create value if this knowledge is not practiced (embedded in a practice). I argue that being able to find at least one practice (way of using) for an offered item makes this item a service. Experiencing the practice with the item in a specific situation then (co-)creates value. To explain the argument I first will identify three realms of signs and their use and then connect these three realms to realms of practices. 


\section{Signs Refer to Signs}

I will use the term "sign" in the following sense: a sign is something that is perceivable, something we become aware of through the senses. I use "sign" and "signifier" synonymously and also to denote arrangements of signs or signifiers, such as words or sentences. We usually take the meaning of signs and signifiers for granted, especially if we experience the pleasant feeling of understanding. As soon as we are confronted with some kind of misunderstanding we experience the fact that signs and signifiers do not carry a specific meaning (or do not carry meaning at all). In the case of misunderstanding we have to discuss or explain what we "mean". Our explanations or discussions usually refer to "real" objects or what we take for real objects and often we do not distinguish greatly between the word in use (signifier) and the object it refers to (signified). In 1928, René Magritte revealed this distinction with his painting "Ceci n'est pas une pipe" ("This is not a pipe", see Fig. 1). In his painting, despite the caption, we see "the pipe" to which the picture refers.

But what if we draw a picture in the vein of Magritte as in Fig. 2, where I used a very wellknown word in Marketing: "loyalty"? We don't have a "real loyalty" to refer to.

Fig. 1: This is an imitation of Magritte's "This is not a pipe". (Source: http://wwmarkt.de/ Pfeifenshop/)

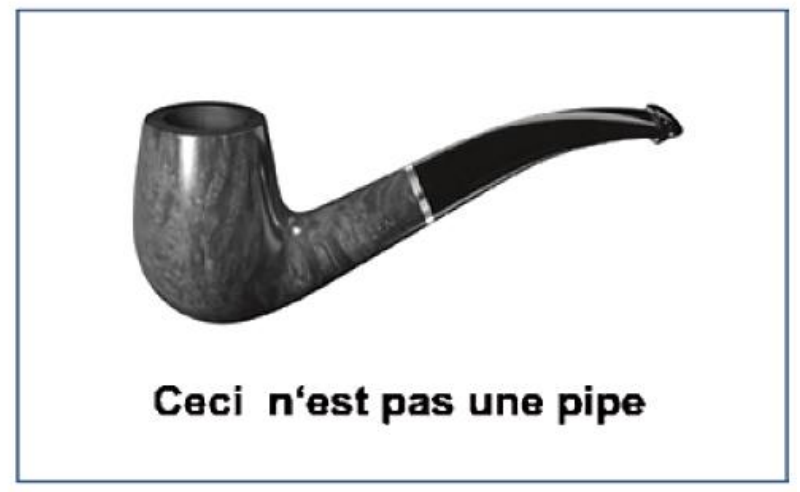

Fig. 2: Loyalty

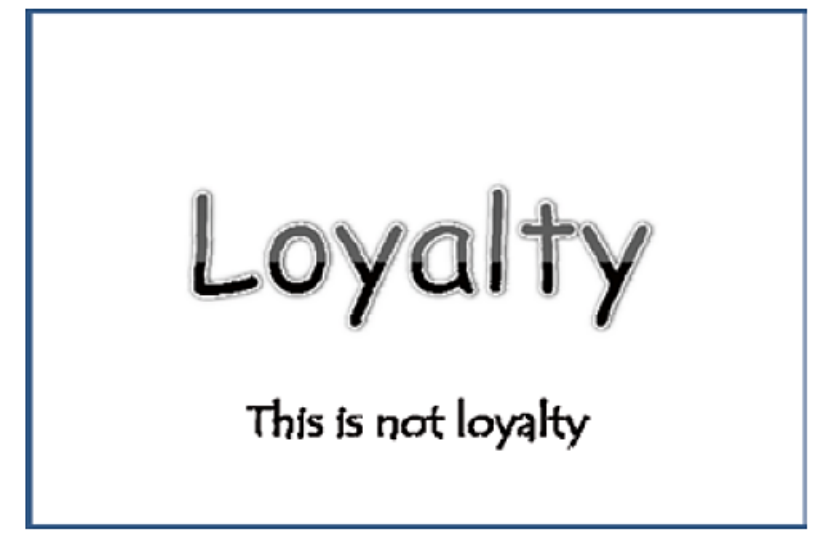

If we explain or discuss "loyalty" we refer to other words, signs or signifiers. Or, in the words of Baudrillard (1975, p. 128), "The sign no longer designates anything at all. It approaches its true structural limit which is to refer back only to other signs". Following Baudrillard (1975, 1998) or Derrida $(1976,1977,1978)$ if talking of signifiers, we have to abstract from the signified, because signifiers only refer back to signifiers and we define/describe words or terms using other words and terms. We do not have access to abstract signifieds, for example "loyalty", outside of language. We can only describe loyalty by using other words. Even if we think about customers and their behavior as a signified for the word "loyalty", as soon as we start to describe the customers or their behavior we are "lost in language use" according to the 
post-structuralist (post-modern) perspective. In marketing, the post-modern perspective has attracted some attention and Firat et al. (1995, pp. 47-48) distinguish three relationships between marketing and post-modernity. In the first relationship, marketing is seen as undergoing some transformations as a result of the impact of post-modern society. The second, a stronger position of marketing in post-modernism, sees marketing as a "primary engine of changes" (Firat et al. 1995, p. 48) in the ongoing transition from modernity to post-modernity. The third perspective, which Firat et al. (1995, p. 48) adopt, sees "an identity [original emphasis] between marketing and post-modernity". Firat and Venkatesh (1993, p. 246) argue that "Marketing is the conscious and planned practice of signification and representation." Whether these representations refer to signifiers or to any signified is still open. Cherrier and Murray (2004, p. 513) conclude "In the post-modern era, there is no longer an attempt to refer back to nature or ground the representamen." One might feel uncomfortable with the idea of being lost in language or signs and might argue that we all know that there is more behind words like 'market' or 'loyalty' than just other words, even though we may have problems describing what there is. Therefore Venkatesh et al. (2006) argue in their emphasis on "(re)considering the starting point of our disciplinary analysis to be the market [...] as opposed to marketing [...]," (Venkatesh et al. 2006, p. 251) "[...] for the imperative of examining the institutionalization of all economies and marketing discourses and practices, [...]"(Venkatesh et al. 2006, p. 257). In their "conceptualization of the market as a sign economy, the market is a mechanism for the exchange of meanings and values for money" (Venkatesh et al. 2006, p. 258). If markets configurate and/or coordinate the exchange of meanings and value for money, two questions may arise: first, that of how the sign economy is linked to activities or actions and, second, that of where the meaning and value come from in a "pure" sign economy.

\section{Signs and Realms of Explicit Coordination}

To answer the second question from the last section I am now going to propose three realms of coordination which use signs (Fig. 3):

Fig. 3: Level of explicit coordination $=$ postmodern abstract systems (Giddens)

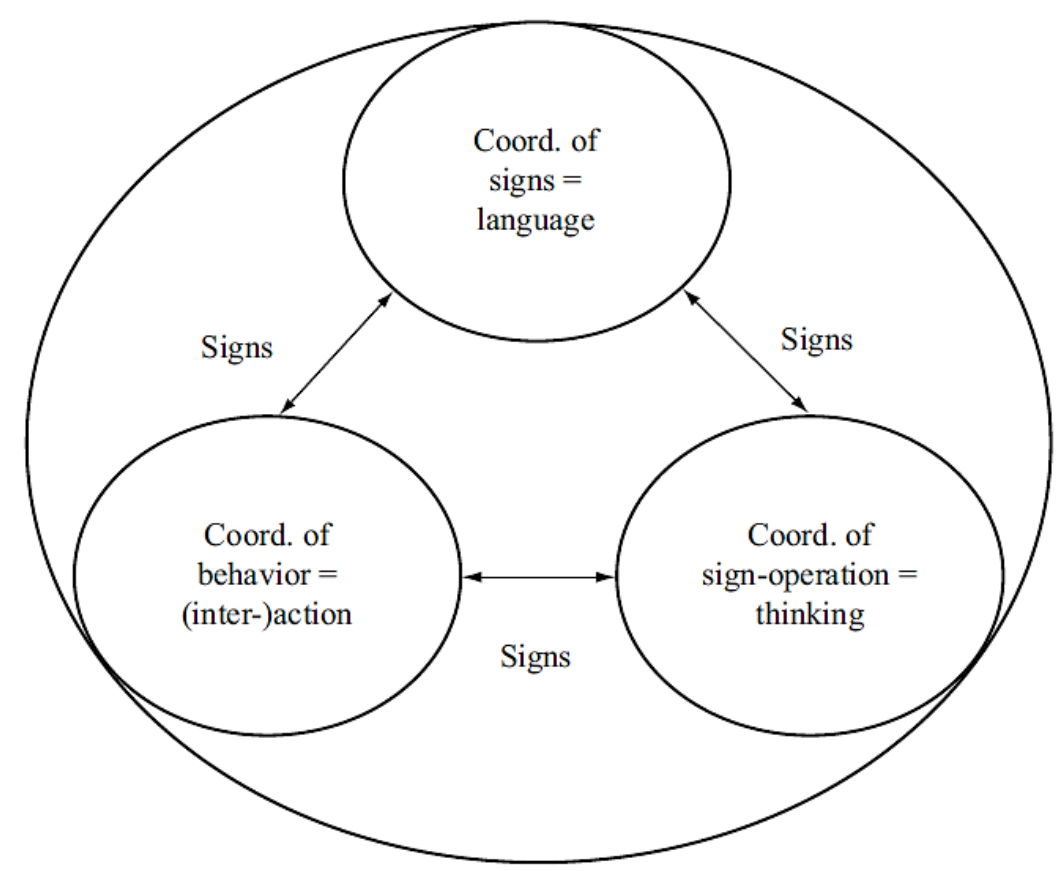




\section{Coordinating Behavior Using Signs}

Starting with the first question from the last section it is evident that signs, signifiers and words are used to support us in many ways. Signs guide us when we are shopping in supermarkets or driving on highways. They give us orientation to find what we are looking for, whether we are looking for a particular product or whether we want to find a certain exit on highway or even the right bathroom. In this sense signs render service in helping to find what we are looking for. All manuals use language and signs to explain what to do with a new device to get it work properly. In addition, signs as words help us to coordinate our interactions. We can tell other people what we want them to do and so on. But we can also use non-verbal signs to coordinate our inter-(actions). So signs are not only signs, they are also service in that they are the "application of skills and knowledge for the benefit of another party" (Vargo and Lusch 2004, p.2). They are service if they coordinate people's behavior. Here we use the word "coordination" to mean that all entities involved in the co-ordination are coordinating as well as coordinated. The Latin roots for "coordination" are "co" for "together" and "ordinare" for "arrange". From this origin "coordination" means "to arrange together". It is the mutual process of the coordinated and the coordinating. The term "coordination" has been used in this vein in team management by Espinosa et al. (2004, p. 112): "a coordination mechanism can be defined as one that helps to manage dependencies. For example, simple things in our daily lives like a traffic light and a flight schedule can be viewed as coordination mechanisms that help us manage our dependencies with other drivers and the airlines, respectively." So signs/signifiers and of course language are used to coordinate behavior, they are service (because they are for others) and they coordinate relationships (because they have an impact on interactions, otherwise we would not use them). There are various ways how signs coordinate behavior. The most common in language use is the imperative or request form-imperative: Do this or that; request: Please do this or that. Behavior is also coordinated by simple signs such as traffic lights or traffic signs. But signs and signifiers are not restricted to coordinating behavior.

\section{Signs Coordinating the Use of Signs}

Using signs, signifiers and words is not limited to the coordination of behavior. We do not only use words to tell others what to do, we also use words to discuss the meaning of words and how to use words. So we use words to coordinate the use of words. Very often we only have other words to express the meaning of the word in question. Definitions use words to coordinate the use of a certain word. According to Tomasello (2008) animals such as apes can use signs to coordinate their behavior but, in contrast to humans, apes cannot use signs to coordinate the use of these signs. This is a specialty of human communication (Tomasello 2008). Maturana and Varela (1987, p. 205) call this specialty of human communication a "language". In their sense a language is a sign system which coordinates the use of the signs of this sign system. Hence the sign system humans have at their disposal is used in two realms: one is to coordinate behavior and the second is to coordinate the use of the signs of the sign system. But there is a third realm of sign use.

\section{Signs and Thoughts}

In a third realm people use language, signs and signifiers to coordinate their thoughts (this does not necessarily mean all thoughts are coordinated by language; architects and engineers may think using other signs than words). The idea goes back to Wittgenstein: “... thinking is essentially the activity of operating with signs." (Wittgenstein 1960, p. 6). So thinking can be understood as coordinating the activity of operating with signs by using these signs and these signs coordinate the activity as they are part of it. Learning could be seen as a change or 
extension of these operations and, in this respect, this part of sign coordination is essential for the potential beneficiary of a service, who has to understand the service proposition somehow. But for the party offering a service it is also important to know that the signs offered are used by the potential beneficiary to co-create value.

\section{Abstract Sign Systems}

Signs and signifiers are not used in isolation; they are linked to other signs and signifiers, as has been discussed before, and we can talk about network of signs or a sign system. These sign systems can be interpreted as Giddens' (1990, p. 22) first type of abstract system: symbolic tokens which are a "media of interchange which can be 'passed around' without regard to the specific characteristics of individuals or groups that handle them at any particular juncture". These abstract systems tend to "lift out" "from local context of interaction and their restructuring across indefinite spans of time-space" (Giddens 1990, p. 21). In a postmodern world this holds especially for sign systems which are "disembedded" (Giddens 1990, p. 21) from local context practices (Schatzki 1996) and in these systems signifiers only relate to signifiers and people wonder what the signified may be. To understand signifiers they have to be re-embedded (Giddens 1990, p. 88) into local context practices.

\section{Practice Theory and Signs}

I started the third section with my understanding of signs and used the term "sign" for everything which is perceivable, everything we become aware of through the senses. So in this sense a sign is explicit, as it can be perceived. Whereas signs are explicit, the meaning of these signs is not always explicit. Here again we can refer to Wittgenstein $(2008, \S 43)$ saying "The meaning of a word is its use in the language." Later in the Philosophical Investigations Wittgenstein $(2008, \S \S 199)$ asks what it means "to obey a rule". He explains that thinking one is obeying a rule, saying one is obeying a rule and obeying a rule is not the same. "Obeying a rule is a practice" (Wittgenstein 2008, § 202). From Wittgenstein's work there is a direct path to Schatzki's (1996) "Practice Theory". "One of the watchwords in contemporary humanistic thought about human activity is 'practice.' [...] For most theorists, meanwhile, the term serves as a signal that such phenomena as identity, language, gender, science, and social organization, which had not been previously construed in the following way, are best thought of as rooted in or as forms of activity." (Schatzki 2007, p. 98). For Giddens, too, practices are the principal unit of investigation: "The basic domain of study of the social sciences, according to the theory of structuration, is neither the experience of the individual actor, nor the existence of any form of societal totality, but social practices ordered across space and time." (Giddens 1984, p. 2).

\section{What are Practices?}

Explicit coordinations are embedded in a lifeworld background (lebensweltlicher Hintergrund) to use Habermas's term (1985a, b) and "[...] in general, cultural theories (and especially theory of practices) relativize the rationalist models of the interest-following or the norm following transparent agent by situating action in implicit or unconscious, collective symbolic structures." (Reckwitz 2002, p. 261) In particular, "Practice theory—as it is exemplified in authors such as Bourdieu, Giddens, late Foucault, Garfinkel, Latour, Taylor or Schatzki-is a type of cultural theory." (Reckwitz 2002, p. 245) Therefore practices may serve as a layer for implicit coordination (Espinosa et al. 2004; Toups and Kerne 2007). 
"A practice is thus a routinized way in which bodies are moved, objects are handled, subjects are treated, things are described and the world is understood." (Reckwitz, 2002, p. 250) "This way of understanding is largely implicit [...]" (Reckwitz 2002, p. 249). The theory of practices has been discussed in marketing, especially in a special issue of Marketing Theory in 2008, and there are attempts to integrate it into a broader service systems perspective (Vargo and Lusch 2010). As a general theory a "[...] practice approach stands in opposition to individualist ontologies where social phenomena are viewed as products arising out of the actions and mental states of individuals, and societism understood as the study of social facts, structures and systems that resist reduction to individual actors." (Araujo et al. 2008, p. 6). According to Warde $(2005$, p. 147) it is in opposition to a sign/ signifier-oriented stream, as he makes clear: "Theories of practice also provide a powerful counterpoint to expressivist accounts of consumption." Simultaneously, Schatzki's notion of practices as a "nexus of doings and sayings" (Schatzki 1996, p. 89) builds an underlying, connecting bridge between expressed sayings and signs on the one hand and doings on the other hand. Schatzki (1996), like Habermas (1985a, 1985b), addresses the implicitness of practices (Schatzki) and the lifeworld background (lebensweltlicher hintergrund, Habermas). In this sense practice theory is not only a nexus of doings and sayings: it also connects body and mind, and the individual subject is the "carrier of the practice" (Reckwitz 2002, p. 250). Hence it serves as an implicit layer in which all explicit coordination is embedded. Practices coordinate ways of doings and sayings, and concomitant practices are created by different ways of doing and sayings. So we see the theory of practices as the link not only between our realms, but also between the different focuses of these realms. Practices are implicitly behind all forms of explicit coordination, they coordinate implicitly, and we can become aware of them by the ways we do or say things. "These practices, overhearing and ambient monitoring, aid in implicit coordination capabilities." (Toups and Kerne 2007, p. 714). Figure 4 shows the realms of sign coordination as a layer of practices: ways of using language, ways of (inter-)acting and ways of thinking. (see Fig. 4)

Fig. 4: Level of implicit coordination $=$ practices

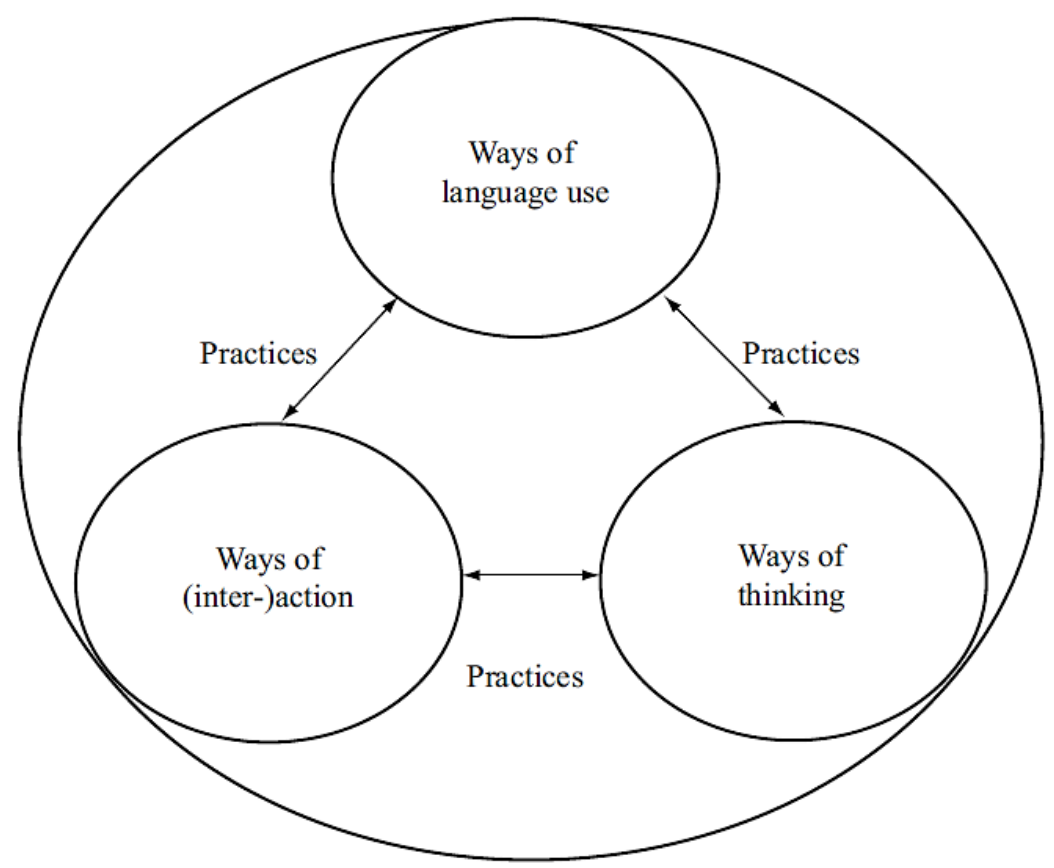




\section{Practices and the Intelligibility of Signs in Service}

As Wittgenstein said, $(2008, \S 43)$ "The meaning of a word is its use in the language." Schatzki (1996, p. 130) explains: "The meanings that humans and situations have for people are not and cannot be exhaustively captured by what they say about these things, a fortiori by the vocabulary employed in discussing them" and further: "For linguistic terms have meaning only in use, and use is a feature of ongoing practices. So the meaning of terms, and therewith the possibilities they mark, are out there in these spatiotemporally evolving entities." (Schatzki 1996, p. 131). Like 'meaning' "intelligibility is ultimately and (one presumes) originally a practical phenomenon that is not entirely recouped in language" (Schatzki 1996, p. 128). Reckwitz (2002, p. 246) emphasises the implicitness of practices by saying: "From the point of view of cultural theory, the seemingly opposed classical figures of the homo economicus and homo sociologicus share a common 'blind spot': they both dismiss the implicit, tacit or unconscious layer of knowledge which enables a symbolic organization of reality."

Schatzki's and Reckwitz's position is very much supported by recent neuro-scientific research. Boulenger et al. (2008, p. 1912) conclude their research results on understanding abstract meanings by saying: "Our results therefore suggest that the orchestration of abstract meaning in the human brain is not solely explained by the activation of unspecific semantic centers in fronto-temporal cortex, but that it involves late complementary activations in the sensory-motor system." D'Ausilio et al. (2009) manipulated speech recognition by activating specific parts of the motor cortex, indicating that the motor cortex (where spatiotemporal movement is "coordinated") activation has a significant impact on speech recognition. Summarizing recent research in neuroscience on "understanding" and "intelligibility" De Jaeger and Di Paolo (2007, p. 502) state: "The findings show that recognition relies on sensor motor coordination, rather than on an individual's capacity to express a confident judgment on whether a stimulus is actually caused by the partner or not."

These results indicate that the spatiotemporal activities where practices take place are important for "localizing" understanding and meaning. This coincides with Habermas's understanding of the lifeworld background (lebensweltlicher Hintergrund, Habermas 1985a, b). As soon as we try to make the implicit explicit we need a different implicit layer serving for understanding and meaning. The ongoing process of explicating the implicit is the process of deconstruction in Baudrillard's $(1975,1998)$ or Derrida's $(1976,1977,1978)$ sense. In any case, we are unable to understand if we lose the lifeworld background, which is mostly implicit.

The latest research in computer science is also looking for intelligibility in spatiotemporal activities or at least where these activities are "planned" in the (pre-)motor cortex: "The aim of this book is to suggest a way of characterizing the syntactic structure of a concrete sentence in natural language as a description or trace of a sensor motor process. My starting point is the hypothesis that the meaning of a sentence should be thought of not as a direct representation of the world, but rather as an evocation of a cognitive process which interfaces with the world via various perceptual and motor mechanisms." (Knott 2010, p. 1)

Lakoff and Jonson (1999, pp. 442 et seq.) have also argued that "Meanings of concepts thus come through embodied experience." They give a lot of examples of spatiotemporal metaphors we use and we live by (Lakoff and Johnson 1999, p. 443):

- States are Locations
○ He's in love
$\circ$ She is a close friend
○ It's out of control 
- Changes are Movements

○ She fell into a depression

- He went crazy

- In the sun clothes went from wet to dry

I have deeper insights now

- Causes are Forces

$\circ$ Her speech moved the crowd

- Their negotiations pulled both sides from the brink of war

- The news propelled the stock market to record heights

To summarize the above I propose that the meaning and intelligibility of signs/signifiers and thus of language in service is achieved by their embeddedness in and their connection to practices. Signs and practices together coordinate people's coexistence and therefore their service and their relationships. It is neither only practice, because it is implicit and cannot be observed directly, nor is it only signs, because they get their meaning and intelligibility through practices. This is shown in Fig. 5:

Fig. 5: Explicit coordination level embedded in implicit coordination

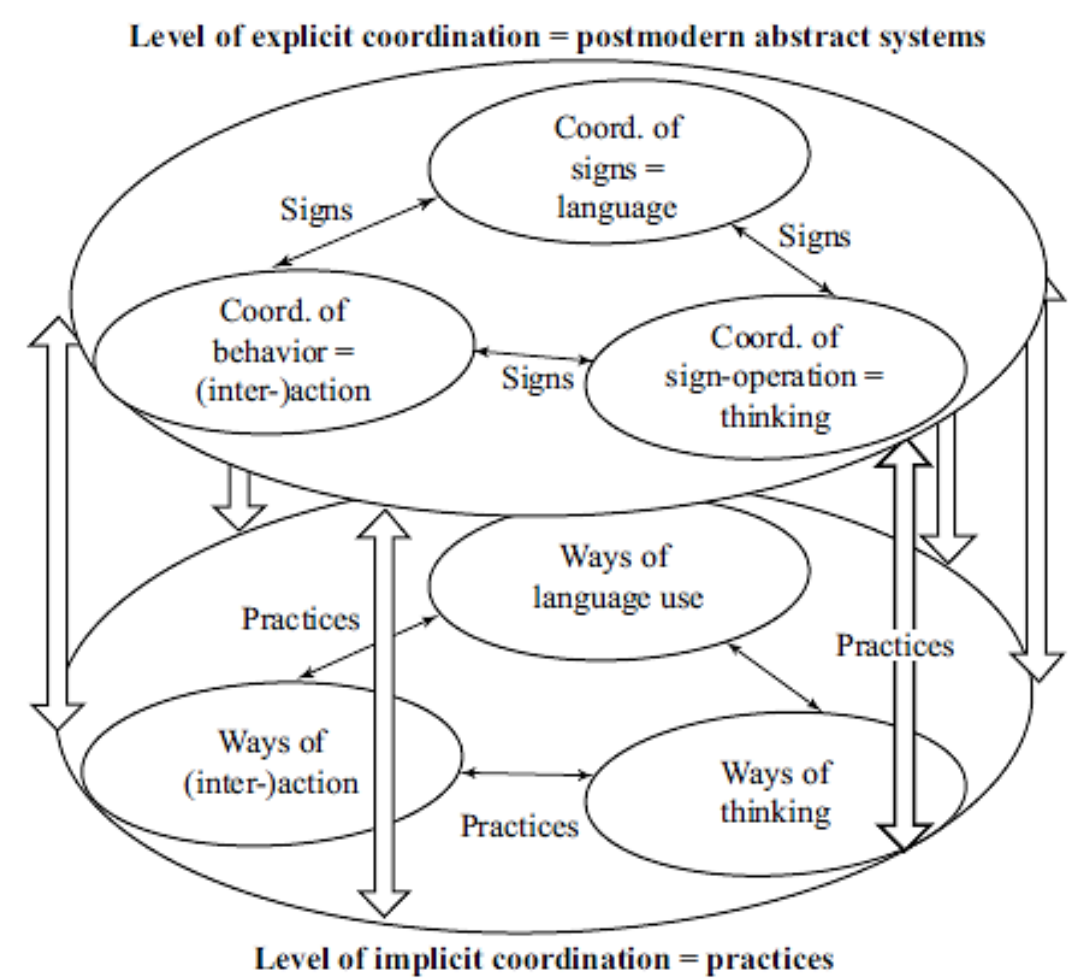

\section{The Re-Embedding of Abstract Systems and the Consequences for Service and Business Relationships}

When we discussed coordination by signs we mentioned the first type of Giddens' abstract systems, the symbolic token. Now we can add the second type of abstract system, which Giddens calls "expert systems", meaning "systems of technical accomplishment or professional expertise that organize large areas of the material and social environments in which we live today" (Giddens 1990, p. 27). According to Giddens (1990, p. 21) these abstract systems are 
disembedding, which "means the 'lifting out' of social relations from local contexts of interaction and their restructuring across indefinite spans of time-space". For example, as lay actors we neither understand the terminology medical doctors use nor have adequate understanding of the way they operate their surgeries. The same is true when lay actors are confronted with lawyers, pilots etc. They use a terminology which is embedded in the practices they are practicing. Lay actors usually do not have access either to the practices or to the terminology. There are millions of symbolic tokens (signs/ signifiers words) out there which are usually not intelligible to lay actors. The greater the division of labor and with it the specialization of work becomes, the more lay actors are confronted with abstract systems with which they are neither familiar with nor fully understand.

At the same time the expert systems and the symbolic tokens render a lot of service they are mainly made for rendering service. And whenever this service is used a relationship is activated.

Here not only lay actors may misunderstand the abstract system but also, vice versa, the expert system may no longer understand the lay actor's perspective, which is well known as the hindsight bias or the knew-it-all-along effect (Hertwig et al. 1997). In project management, too, Addison (2003, p. 25) found that "Misunderstanding the users' requirements emerged as the most significant risk [...]". And even worse, as the above analysis shows, misunderstandings on both sides cannot be resolved by offering more information if this information is not embedded in the participants' practice world. The overall challenge in service is that if it is offered by an abstract system the expert system and the lay actors have to co-create an explicit and implicit means of coordination. And from this perspective it is an illusion that "merchants need contracts not only to secure their legal rights, but also to prevent consumer misunderstandings" (Fazlollahi 2002, p. 69). Contracts only avoid misunderstanding if the law on which they are based is consistent with the practices of the participating partners and their social systems. And from our perspective this is essentially the value of contracts and law: that a misunderstanding does not have to be resolved by a long-lasting, costly co-creation of coordination and meaning by the involved parties, but it is "resolved" from a third party's perspective: by the judge. Of course this process may not always satisfy all participating parties and so a more win-win approach is to find joint meanings and practices during the process of cooperation, hence avoiding dissatisfying judgments by third parties.

The framework presented here should help to offer appropriate service by an expert system or abstract system in general as it shows that misunderstanding is not an issue of right or wrong but an issue of different practices. If the practices were not different service would not be possible. The different ways in which we (inter-)act, talk and think is the basis for service, its exchange and the co-creation of value. Service providers should be aware of the importance of the practices of their customers. Customers may not be able to describe their practices because they are mainly implicit and often taken for granted. In these cases market research by classical questionnaires does not help to identify customers' practices. Market researchers have to find methods to identify and understand their customers' practices, which may be out of the realm of language.

\section{Endnote}

1 For the discussion of Bourdieu's, Giddens', and Lyotard's account on Practice theory see Schatzki 1996, pp 133. 


\section{References}

Addison, T. (2003). E-commerce project development risks: Evidence from a Delphi survey. International Journal of Information Management, 23(1), 25-40. doi:10.1016/S0268-4012(02) 00066-X

Araujo, L., Kjellberg, H., \& Spencer, R. (2008). Market practices and forms: Introduction to the special issue. Marketing Theory, 8(1), 5-14. doi:10.1177/1470593107086481

Baudrillard, J. (1975). The mirror of production. (trans: Poster, M.). St. Louis: Telos Press (Original work published 1973).

Baudrillard, J. (1998). The consumer society: Myths and structures. (trans: Turner, C.). Paris: SAGE (Original work published 1970).

Boulenger, V., Hauk, O., \& Pulvermüller, F. (2008). Grasping ideas with the motor system: Semantic somatotopy in idiom comprehension. Cerebral Cortex, 19(8), 1905-1914. doi: 10.1093/cercor/bhn217

Cherrier, H., \& Murray, J. B. (2004). The sociology of consumption: The hidden facet of marketing. Journal of Marketing Management, 20(5/6), 509-525.

D’Ausilio, A., Pulvermüller, F., Salmas, P., Bufalari, I., Begliomini, C., \& Fadiga, L.

(2009). The motor somatotopy of speech perception. Current Biology, 19(5), 381-385.

doi:10.1016/j.cub.2009.01.017

De Jaegher, H., \& Di Paolo, E. (2007). Participatory sense-making: An enactive approach to social cognition. Phenomenology and Cognitive Science, 6(4), 485-507. doi:10.1007/s11097-007-9076-9

Derrida, J. (1976). Of grammatology. (trans: Spivak, G. C.). Baltimore: John Hopkins University Press (Original work published 1967).

Derrida, J. (1977). Signature event context. Glyph, 1, 172-197.

Derrida, J. (1978). Writing and difference. (trans: Bass, A.). Chicago: The University of Chicago Press.

Espinosa, J. A., Lerch, F. J., \& Kraut, R. E. (2004). Explicit versus implicit coordination mechanisms and task dependencies: One size does not fit all. In E. Sales \& S. M. Fiore (Eds.),

Team cognition: Understanding the factors that drive process and performance (pp. 107-129).

Washington, DC: American Psychological Association.

Fazlollahi, B. (2002). Stratregies for eCommerce success. London: IRM Press.

Firat, A. F., \& Venkatesh, A. (1993). Postmodernity: The age of marketing. International Journal of Research in Marketing, 10(3), 227-249. doi:10.1016/0167-8116(93)90009-N

Firat, A. F., Dholakia, N., \& Venkatesh, A. (1995). Marketing in a postmodern world. European Journal of Marketing, 29(1), 40-56. doi:10.1108/03090569510075334

Friedland, R., \& Alford, R. R. (1991). Bringing society back in: Symbols, practices, and institutional contradictions. In W. W. Powell \& P. J. DiMaggio (Eds.), The new institutionalism in organizational analysis (pp. 232-263). Chicago: The University of Chicago Press.

Gergen, K. J. (1991). The saturated self: Dilemmas of identity in contemporary life. New York: Basic Books.

Gergen, K. J. (1994). Realities and relationships: Soundings in social construction. Cambridge: Harvard University Press.

Gergen, K. J. (1999). An invitation to social construction. London: SAGE.

Giddens, A. (1984). The constitution of society: Outline of the theory of structuration. Cambridge: 
Polity Press.

Giddens, A. (1990). The consequences of modernity. Cambridge: Polity Press.

Habermas, J. (1985a). The theory of communicative action: Vol. 1. Reason and the rationalization of society. Boston: Beacon Press.

Habermas, J. (1985b). The theory of communicative action: Vol. 2. Lifeword and system: A critique of functionalist reason. Boston: Beacon Press.

Hertwig, R., Gigerenzer, G., \& Hoffrage, U. (1997). The reiteration effect in hindsight bias. Psychological Review, 104(1), 194-202. doi:10.1037/0033-295X.104.1.194

Knott, A. (2010). Sensorimotor cognition and natural language syntax (draft: June 2010).

Lakoff, G., \& Johnson, M. (1999). Philosophy in the flesh. New York: Basic Books.

Matten, D., \& Moon, J. (2008). "Implicit" and "explicit" CSR: A conceptual framework for a comparative understanding of corporate social responsibility. Academy of Management Review,

33(2), 404-424.

Maturana, H., \& Varela, F. J. (1987). The tree of knowledge: The biological roots of human understanding. Boston: Shambhala Publications.

Reckwitz, A. (2002). Toward a theory of social practices: A development in culturalist theorizing. European Journal of Social Theory, 5(2), 243-263.

Schatzki, T. (1996). Social practices: A Wittgensteinian approach to human activity and the social. Cambridge: Cambridge University Bridge.

Schatzki, T. R. (2007). Introduction. Human Affairs, 17(2), 97-100. doi:10.2478/v10023-0070009-6

Tomasello, M. (2008, May 25). How are humans unique? New York Times Magazine. Retrieved from http://www.nytimes.com/2008/05/25/magazine/25wwln-essay-t.html

Toups, Z. O., \& Kerne, A. (2007). Implicit coordination in firefighting practice: Design implications for teaching fire emergency responders. Proceedings of the SIGCHI conference on Human factors in computing systems (pp. 707-716). San Jose, Californien: CHI.

UNESCO. (1968). Illiteracy and human rights. Villeneuve-Saint-Georges: Union Typographique.

Vargo, S. L., \& Lusch, R. F. (2004). Evolving to a new dominant logic for marketing. Journal of Marketing, 68(1), 1-17.

Vargo, S. L., \& Lusch, R. F. (2008). Service-dominant logic: Continuing the evolution. Journal of the Academy of Marketing Science, 36(1), 1-10. doi:10.1007/s11747-007-0069-6

Vargo, S. L., \& Lusch, R. F. (2010). It's all B2B... and beyond: Toward a systems perspective of the market. Industrial Marketing Management (in press)

Venkatesh, A., Penaloza, L., \& Firat, A. F. (2006). The market as a sign system and the logic of the market. In R. F. Lusch \& S. L. Vargo (Eds.), The service-dominant logic of marketing, dialog, debate and directions (pp. 251-265). New York: M.E. Sharpe.

Warde, A. (2005). Consumption and theories of practice. Journal of Consumer Culture, 5(2), 131-153. doi:10.1177/1469540505053090

Wittgenstein, L. (1960). The blue and brown books. New York: Harper and Row.

Wittgenstein, L. (2008). Philosophical investigations: The german text, with a revised english translation. Oxford: Blackwell Publishing. 